\title{
Validación de una estrategia metodológica para la evaluación cualitativa de un pastizal mediano abierto del estado de Zacatecas
}

\section{Validation of a methodological strategy for the qualitative evaluation of semiarid rangelands in Zacatecas}

\author{
Francisco Guadalupe Echavarría-Cháireza, Juan Luis Santos de la Cruz ${ }^{\mathrm{b}}$, Ramón \\ Gutiérrez Lunaa, Guillermo Medina García
}

\begin{abstract}
RESUMEN
La degradación continua de los pastizales debido a una deficiente planeación en la producción ganadera de tipo extensivo, hace necesario el monitoreo rutinario del estado de salud de los agostaderos. Por ello, se requiere establecer un protocolo de seguimiento por medio de metodologías confiables, rápidas y económicas. Una metodología que se ha utilizado es por medio del registro de 17 indicadores del suelo, agua y vegetación. La metodología se aplicó en 34 sitios del pastizal mediano abierto del estado de Zacatecas con cuatro repeticiones por sitio. Con los valores estimados por componentes principales se calculó un semivariograma y por interpolación con Kriging, se generaron tres mapas y se compararon con mapas de referencia generados por estudios de tipo cuantitativo para valorar su coincidencia. El primer mapa se asoció con estadios de salud del pastizal utilizando un mapa de referencia con valores del "índice de vegetación de diferencia normalizada" (NDVI); el segundo mapa identifica las zonas más afectadas por el escurrimiento, y el tercero identifica las zonas afectadas por la erosión hídrica. Los mapas se generaron con modelos matemáticos. La coincidencia entre mapas generados por componentes principales y mapas de referencia fue de $59.2,31.2$ y $17.2 \%$, los cuales fueron cercanos a los valores de varianza estimados por los componentes principales, así como la igualdad $(P>0.05)$ entre los valores categóricos, permitieron validar la correspondencia entre ambos métodos.
\end{abstract}

PALABRAS CLAVE: Indicadores de salud, Componentes principales, Kriging, Salud del pastizal.

\begin{abstract}
Rangeland degradation due to mismanagement practices in the extensive system for cattle and the need for monitoring rangelands continuously, leads to seek for methodologies which may be easily and quickly applied. In order to accomplish such objectives, methodologies must be based upon qualitative indicators. Such methodology has been applied broadly using 17 indicators that represent soil, water and vegetation attributes. This study was carried out in the State of Zacatecas and included 34 sites located randomly in the grassland with four repetitions by site. Data was analysed by principal components and a semivariogram and maps were generated by Kriging. Further, maps were compared to reference maps, which were calculated by quantitative methods. First map was associated to rangelands general health condition. The reference map was estimated from NDVI values. The second component refers to runoff, and the third component was associated to water erosion induced by bare soil. Those two were compared to reference maps estimated from mathematical models. Coincidences among maps were as $59.2,31.2$ y $\mathbf{1 7 . 2} \%$, which were the variance values estimated by principal components, and allowed to validate correspondence between them. Categorical data were not different $(P>0.05)$. Low cost and easy methods are helpful and should be validated for use them when no other methods are available.
\end{abstract}

KEY WORDS: Rangeland, Principal components, Kriging, Grasslands health.

Recibido el 28 de febrero de 2014. Aceptado el 14 de mayo de 2014.

a Campo Experimental Zacatecas, INIFAP. Km 24.5 Carretera Zacatecas-Fresnillo, 98500, Calera, Zacatecas. México. fechava@zacatecas.inifap.gob.mx. Correspondencia al primer autor.

b Área de Ciencias de la Salud. Universidad Autónoma de Zacatecas. México. 


\section{INTRODUCCIÓN}

Zacatecas cuenta con 5.5 millones de hectáreas dedicadas al pastoreo extensivo, de ellas, 2.3 millones se consideran con un alto nivel de degradación(1). El continuo deterioro debido al mal manejo de los recursos naturales y los efectos climáticos, han repercutido sobre la condición del pastizal mediano abierto. La producción de materia seca de los agostaderos de Zacatecas, ha ido disminuyendo de manera gradual, como consecuencia de la continua degradación. Existe una correspondencia entre la degradación del suelo con la consecuente disminución de la producción de materia seca(2). La pérdida del horizonte superficial $A$, puede representar una disminución de $200 \mathrm{~kg} / \mathrm{ha} / a n ̃ o$ de materia seca, pero en ocasiones, cuando se ha perdido también el horizonte $\mathrm{B} \circ \mathrm{C}$, las pérdidas llegan a ser superiores a $1 \mathrm{t} / \mathrm{ha} / \mathrm{anno}(2)$.

Además, la atención gubernamental y sus programas, tradicionalmente atienden los efectos en el componente animal, por lo que el pastizal es un recurso al que se le ha dado poca importancia, debido a la complejidad y magnitud del mismo. En ellos existe flora y fauna que sustentan a la sociedad, pero además son sitios de recarga de acuíferos(3), los que favorecen la realización de labores productivas en la cuenca baja. Sin embargo el uso sin orden de los pastizales ha tenido repercusiones de grandes dimensiones como erosión del suelo, disminución de diversidad de flora y fauna así como una baja producción animal. Para lograr un conocimiento continuo de la tendencia de la condición del pastizal que permita regular el uso, se requiere utilizar metodologías de uso sencillo y confiables, capaces de ofrecer una valoración cualitativa de la condición del pastizal, por ello, en este estudio se contrasta la metodología de "salud del pastizal"(4) con mediciones cuantitativas realizadas independientemente, para establecer el grado de confianza de esta metodología.

El seguimiento de las pérdidas de suelo y productividad del agostadero son necesarias

\section{INTRODUCTION}

Zacatecas has 5.5 million hectares devoted to extensive grazing, of which 2.3 million are considered with a high level of degradation(1). The continued deterioration due to mismanagement of natural resources and climate effects have affected the condition of the semiarid rangelands. The dry matter production of the rangelands of Zacatecas has been declining gradually due to the continuous degradation. There is a relationship between land degradation and the consequent decrease in dry matter production(2). The loss of topsoil A, may represent a decrease of $200 \mathrm{~kg} / \mathrm{ha} / \mathrm{yr}$ of dry matter, but sometimes, when the horizon of points B or C, has been lost, decreases become greater than $1 \mathrm{t} / \mathrm{ha} / \mathrm{yr}(2)$.

In addition, government attention and its programs, traditionally attend to the effects in the animal component, hence that the pasture is a resource that has been given little importance due to the complexity and magnitude. In them there is flora and fauna that sustain society, but also are aquifer recharge sites(3), favoring productive work in the lower basin. However, the use of rangelands has had large impacts such as soil erosion, decreased diversity of flora and fauna as well as low animal production. To achieve a continuous understanding of the tendency of range condition for regulating the use, it is required to use methodologies simple and reliable, able to provide a qualitative assessment of range condition; therefore, in this study contrasts to the "rangeland health" methodology(4) with quantitative measurements carried out independently to establish the confidence in this methodology.

Monitoring of the soil and rangeland productivity losses are necessary for decision making of improvement and recovery of the same. Due to the complexity in these determinations, qualitative simple tools have been developed which are easy and inexpensive, and can be useful for decision making(5). 
para la toma de decisiones de mejoramiento y recuperación del mismo. Debido a la complejidad en estas determinaciones, se han desarrollado herramientas cualitativas, sencillas y de bajo costo, las cuales pueden ser útiles para la toma de decisiones(5).

Recientemente un panel de expertos de la "Society for Range Management" y el "National Research Council" propusieron que la salud de los pastizales se puede determinar por medio de la evaluación del potencial ecológico de un sitio para conservar los recursos, a través de una serie de indicadores de procesos ecológicos y por la estabilidad del sitio. Con base en estas recomendaciones, se desarrolló un método cualitativo para evaluar la salud de los pastizales en un punto específico del tiempo, con el uso de 17 indicadores enmarcados en tres atributos: estabilidad del suelo y sitio, funcionalidad hidrológica e integridad biótica $(4,5)$.

Sin embargo, es necesario que dichas metodologías sean comparadas y validadas con el uso de métodos de evaluación cuantitativos. La correspondencia entre métodos cualitativos y cuantitativos sirve tanto para hacer ajustes metodológicos, como para dar certeza y confiabilidad. Por ello, el presente estudio tuvo por objetivo el validar el uso de métodos cualitativos, y compararlos con estudios de tipo cuantitativo, bajo la hipótesis de que ambos deberán corresponderse entre sí.

\section{MATERIALES Y MÉTODOS}

El estudio se realizó en el estado de Zacatecas, el cual se localiza entre los $25^{\circ} 07^{\prime}-21^{\circ} 01^{\prime} \mathrm{N}$ y $100^{\circ} 43^{\prime}-104^{\circ} 22^{\prime} \mathrm{O}$. Cuenta con una superficie de $7{ }^{\prime} 553,930$ ha que representan el $3.8 \%$ de la superficie territorial del país(6). El clima de acuerdo con Köppen corresponde al tipo B (secos) en el $80 \%$ de la superficie, C (templados) en $19 \%$ y $\mathrm{A}$ (cálido húmedos) en $1 \%(7)$.

La vegetación de Zacatecas incluye siete tipos de vegetación(8): bosque de coníferas y
Recently a panel of experts from the "Society for Range Management" and the "National Research Council" proposed that the health of grasslands can be determined by evaluating the ecological potential of a site to conserve resources through a number of indicators of ecological processes and the stability of the site. Based on these recommendations, a qualitative method was developed to assess the health of grasslands at a specific point in time, using 17 indicators framed on three attributes: soil and site stability, hydrologic function and biotic integrity $(4,5)$.

Nevertheless, it is necessary that these methodologies can be compared and validated using quantitative methods of evaluation. The relationship between qualitative and quantitative methods serves both to make methodological adjustments, as well as to provide certainty and reliability. Therefore, this study is aimed to validate the use of qualitative methods and compared with quantitative studies, under the hypothesis that both must match each other.

\section{MATERIALS AND METHODS}

The study was conducted in the State of Zacatecas, which is located between $25^{\circ} 07^{\prime}$ $21^{\circ} 01^{\prime} \mathrm{N}$ and $100^{\circ} 43^{\prime}-104^{\circ} 22^{\prime} \mathrm{W}$. It has an area of 7,553,930 ha and represents $3.8 \%$ of the land area of the country(6). The climate according to Köppen corresponds to B type (dry) in $80 \%$ of the surface, $C$ type (temperate) in $19 \%$ and $A$ type (warm humid) in $1 \%(7)$.

The vegetation of Zacatecas includes seven vegetation types(8): forest of conifers and conifers hardwood, hardwood, desert scrub, mezquital, sub caducifolia, and deciduous forest and grassland; among them is the rangelands, the object of this study.

Semiarid rangelands are located in dry temperate climate with warm summers, they are classified as $\mathrm{BS}_{1} \mathrm{kw}$; with annual average temperature of 15 to $18{ }^{\circ} \mathrm{C}$ and average annual rainfall of $355 \mathrm{~mm}(9)$. They mainly deals with 
coníferas latifoliadas, latifoliadas, matorral xerófilo, mezquital, selva caducifolia y subcaducifolia y pastizal; entre los cuales está el mediano abierto, objeto de este estudio.

El pastizal mediano abierto se localiza en clima seco templado, con verano cálido, clasificado como $\mathrm{BS}_{1} \mathrm{kw}$; temperatura media anual de 15 a $18{ }^{\circ} \mathrm{C}$ y precipitación promedio anual de 355 $\mathrm{mm}(9)$. Ocupa principalmente terrenos que presentan pendientes de 0 a $40 \%$, es decir ondulados, suavemente ondulados, suavemente quebrados o cerriles y escarpados, con relieve normal a excesivo. Las características de sus suelos son: ígneos y calizos, texturas arcillosa, franco arenosa, franco arcillosa, estructura granular y bloque sub-angular; color castaño rojizo o grisáceo claro, los cuales presentan erosión hídrica laminar ligera y eólica. Las principales especies que caracterizan a esta comunidad vegetal son Bouteloua gracilis (Willd. ex Kunth) Lag. ex Steud., B. Curtipendula (Michx.) Torr., B. Hirsuta Lag., Lycurus phleoides Kunth., Buchloe dactyloides (Nutt.) Engelm, Aristida wrigthii (Nash) Setaria macrostachya Kunth(9). Geográficamente se distribuye desde los municipios de Sombrerete, Miguel Auza y Juan Aldama, hasta llegar al municipio de Pinos, Zacatecas.

\section{Estudio de campo}

El muestreo consideró 17 indicadores considerados para pastizal mediano abierto. Los sitios estudiados, en su mayoría se localizan, en la parte central del Estado, entre las coordenadas: $25^{\circ} 09^{\prime}, 21^{\circ} 04^{\prime} \mathrm{N}$; y $100^{\circ} 49^{\prime}$, $104^{\circ} 19^{\prime} \mathrm{O}(8)$ Los sitios de pastizal mediano abierto se ubicaron por medio de los mapas del inventario nacional forestal de la UNAM(10).

Se seleccionaron, al azar, 34 sitios para realizar la evaluación de la salud del pastizal mediano abierto. En principio dentro de cada sitio ecológico (localidad) estudiado se ubicó al de mayor calidad (mejor condición ecológica del sitio), es decir un tipo de tierra con lands that have slopes 0 to $40 \%$, i.e. wavy, gently undulating, gently broken or rough and steep, normal to excessive relief. The characteristics of the soils are igneous and limestone, clay textures, sandy loam, clay loam, granular structure and sub-angular block; reddish brown or light gray, which exhibit laminar light water erosion and wind. The main species that characterize this plant community are Bouteloua gracilis (Willd. ex Kunth) Lag. ex Steud., B. Curtipendula (Michx.) Torr. B. Hirsuta Lag., Lycurus phleoides Kunth., Buchloe dactyloides (Nutt.) Engelm, Aristida wrigthii (Nash), and Setaria macrostachya Kunth(9). They are geographically distributed from the municipalities of Sombrerete, Miguel Auza and Juan Aldama, including the Municipality of Pinos, Zacatecas.

\section{Field study}

The sampling methodology considered 17 indicators for rangelands. The sites studied, most are located in the central part of the State, between the coordinates: $25^{\circ} 09^{\prime}$ and $21^{\circ} 04^{\prime}, \mathrm{N} ; 100^{\circ} 4^{\prime}$ and $104^{\circ} 1^{\prime} \mathrm{W}(8)$. Rangelands sites were found using the national forest inventory maps UNAM(10).

Thirty four (34) sites were randomly selected for assessing the health of rangelands. In principle within each ecological site (location) studied, the highest quality area was ranked (in terms of better ecological condition of the site), i.e. a type of land with specific physical characteristics with capacity for greater diversity and plant production and increased responsiveness to ecological management. These were considered as reference sites for later comparison with the other sampled areas from the same locality. Geographic location of each site was recorded using a GPS model Garmin $\AA$, with $3 \mathrm{~m}$ of precision in order to perform a spatial analysis.

Evaluations conducted in each selected site consisted of categorical field measurements, in which values of the type of vegetation and 
características físicas específicas con capacidad para mayor diversidad y producción vegetal, así como mayor capacidad de respuesta al manejo ecológico, considerándose estos como sitios de referencia para posteriormente compararse con los demás puntos muestreados de la misma localidad. Se estableció la ubicación geográfica para cada sitio por medio de un GPS marca Garmin $®$, con 3 m de precisión, con el fin de realizar un análisis espacial.

Las evaluaciones realizadas en cada sitio seleccionado consistieron en mediciones categóricas de campo, en las cuales se asignaron valores del tipo de vegetación y atributos del ecosistema, de acuerdo con los 17 indicadores establecidos en la metodología utilizada(4), en donde se señala que la salud del pastizal puede resumirse en tres atributos:

1) Estabilidad del sitio/suelo: que es la capacidad de un sitio para delimitar la redistribución y pérdida de los recursos del suelo (incluyendo nutrientes y material orgánico) por el agua y viento. 2) Funcionalidad hidrológica, que es la capacidad de un sitio para capturar, almacenar y liberar algo del agua de lluvia, escurrimientos y nieve (cuando aplique), resistir una reducción en esta capacidad y recobrar esta capacidad después de una degradación. 3) Integridad biótica, que es la capacidad de un sitio para mantener características funcionales y una estructura de las comunidades en un contexto de variabilidad normal, resistir la pérdida de esa función y estructura debido a un disturbio, y recobrarse después del mismo.

Con el fin de obtener un valor categórico de cada uno de los indicadores de la salud, se utilizó una escala ordinal asignando un valor ascendente a partir de uno, el cual se otorga a una condición extrema (1) seguido por el intervalo de moderada a extrema (2), de moderada (3), de ligera a moderada (4) y, de nula a ligera (5), a cada uno de los 17 indicadores (Cuadro 1) de la salud del pastizal a todos los sitios muestreados y sus repeticiones, usando como referencia el sitio ideal ya seleccionado previamente. ecosystem attributes were recorded according to the 17 indicators set out in the methodology(4). These were assigned so that rangeland health can be summarized in three attributes:

1) Stability of the site/soil, it is the ability of a site to delimit the redistribution and loss of soil resources (including nutrients and organic material) by water and wind. 2) Hydrological functionality, which is the ability of a site to capture, store and release some of rainwater, runoff and snow (when applicable), to resist a reduction in this capacity and regain this ability after degradation. 3) Biotic integrity, which is the ability of a site to maintain functional characteristics and structure of communities in a context of normal variability, resisting the loss of the function and structure due to a disturbance, and recover afterwards.

In order to obtain categorical of each of the health indicators, assigning from one value on upward used an ordinal scale. Extreme conditions were given a value of one (1), followed by a moderate to extreme interval (2), moderate (3), mild to moderate (4), and zero to light (5). This was carried out for each of the 17 indicators (Table 1 ) of rangeland health for all sampled sites and its repetitions, using as reference the ideal site previously selected.

\section{Analysis of the information}

With the information obtained, a principal components analysis was carried out for each site; it was found that the first three components provide the largest contribution that better explained the variance(11). These were selected and each component was named according to the prevailing values of the variables (magnitude of the characteristic vectors or eigenvectors). Subsequently, the new values of each site with the use of the components were obtained. These were associated with their geographical coordinates to develop a variogram, which was calculated using the $\mathrm{GS}^{+(12)}$ program, and thus 
Francisco Guadalupe Echavarría-Cháirez, et al. / Rev Mex Cienc Pecu 2015;6(2):171-191

Cuadro 1. Indicadores que califican a los atributos del ecosistema: estabilidad de suelo/sitio (SS), funcionalidad hidrológica (HF) e integridad biótica (BI)

Table 1. Indicators qualifying ecosystem attributes: stability of soil/site (SS), hydrologic function (HF) and biotic integrity $(\mathrm{BI})$

\begin{tabular}{|c|c|c|c|c|}
\hline \multirow[b]{2}{*}{ Indicators } & \multirow[b]{2}{*}{ Physical attributes observed in grassland } & \multicolumn{3}{|c|}{ Health features } \\
\hline & & SS & $\mathrm{HF}$ & $\mathrm{Bl}$ \\
\hline 1 & Rills & $\mathrm{X}$ & $X$ & \\
\hline 2 & Water flow patterns & $\mathrm{X}$ & $X$ & \\
\hline 3 & Pedestals or terracettes & $\mathrm{X}$ & $X$ & \\
\hline 4 & Bare ground & $\mathrm{X}$ & $X$ & \\
\hline 5 & Gullies & $\mathrm{X}$ & $X$ & \\
\hline 6 & Wind-Scoured, blowout, and/or depositional areas & $\mathrm{X}$ & & \\
\hline 7 & Litter movement & & $X$ & \\
\hline 8 & Soil surface resistance to erosion & $\mathrm{X}$ & $X$ & $\mathrm{X}$ \\
\hline 9 & Soil surface loss or degradation & $\mathrm{X}$ & $x$ & $\mathrm{X}$ \\
\hline 10 & $\begin{array}{l}\text { Plant community composition and distribution } \\
\text { relative to infiltration and runoff }\end{array}$ & & $X$ & \\
\hline 11 & Compaction layer & $\mathrm{X}$ & $x$ & $\mathrm{X}$ \\
\hline 12 & Functional/structural groups & & & $\mathrm{X}$ \\
\hline 13 & Plant mortality/decadence & & & $\mathrm{X}$ \\
\hline 14 & Litter amount & & $x$ & $X$ \\
\hline 15 & Annual production & & & $X$ \\
\hline 16 & Invasive plants & & & $X$ \\
\hline 17 & Reproductive capacity of perennial plants & & & $\mathrm{X}$ \\
\hline
\end{tabular}

Pellant et al., 2003(4).

Análisis de la información

Con la información obtenida se realizó un análisis de componentes principales para cada sitio, de los cuales se seleccionaron los tres primeros componentes que son los de mayor aportación y que mejor explican la varianza(11). Cada componente se denominó de acuerdo a los valores predominantes de las variables (magnitud de los vectores característicos o eigenvectors); posteriormente, se obtuvieron los nuevos valores de cada sitio con el uso de los componentes, y estos se asociaron con sus coordenadas geográficas para elaborar un semivariograma, el cual se calculó en el programa GS+(12), y de esta manera se verificó la correlación espacial. Posteriormente se elaboraron mapas en IDRISI(13) para extrapolar los resultados hacia las áreas no muestreadas the degree of spatial dependence was verified. Later, maps were drawn in IDRISI(13) to extrapolate the results in areas not sampled of rangelands, and the results were presented at the municipality level, which provides a more precise methodology and allows comparison with other quantitative studies.

\section{Validation of the information}

For validation of the results, quantitative estimates made in previous studies were compared with the definition of estimated principal components obtained. For this study, the first three components were considered largely influenced by the overall health of pasture runoff and water erosion, based on the magnitude of the characteristic vectors. 
del pastizal mediano, y presentando los resultados a nivel de Municipio, lo que proporciona una mayor precisión a la metodología utilizada y permite su comparación con otros estudios cuantitativos.

\section{Validación de la información}

Para realizar la validación de los resultados, se utilizaron estimaciones de tipo cuantitativo, elaboradas en estudios previos, que correspondieran con la definición de los componentes principales estimados. En el caso de este estudio, los tres primeros componentes se consideraron mayormente influenciados por la salud general del pastizal, el escurrimiento y la erosión hídrica, basados en la magnitud de los vectores característicos.

Para el caso de la comparación de cada componente principal se utilizaron mapas elaborados de investigaciones previas para el estado de Zacatecas $(1,14)$. Dado que el primer componente se definió como el que hace referencia a la "salud general del pastizal", su contraparte cuantitativa utilizada fue el "índice de vegetación de diferencia normalizada" (NDVI, por sus siglas en inglés)(15). El NDVI es un índice que fue originalmente propuesto como un medio para estimar biomasa verde(15), ya que es un indicador de la cantidad de vegetación existente y qué tan verde es en ese momento. El NDVI se obtiene a partir de imágenes de satélite y relaciona la reflexión en la región roja (absorción máxima cercana a la clorofila $\alpha$ ) y la región del infrarrojo cercano (NIR) a través de la siguiente expresión: NDVI = (NIR-ROJO) / (NIR+ROJO), en la imagen de satélite. Este índice representa la diferencia en la absorción y reflexión de la longitud de onda del rojo, la cual es fuertemente absorbida por la vegetación verde, y la longitud de onda del infrarrojo cercano, la cual es fuertemente reflejada por la vegetación verde(16).

Las bases de la relación entre el NDVI y la biomasa verde parecen estar relacionadas con la cantidad de radiación fotosintéticamente
For the case of comparing each principal component, maps drawn from previous studies for the state of Zacatecas were used $(1,14)$. Since the first component was defined as referring to the "general health of the rangeland", its quantitative counterpart used was the "normalized difference of vegetation index" (NDVI)(15); index, which was originally proposed as a means to estimate green biomass(15), it is an indicator of the amount of vegetation and how green an area is in time. The NDVI is obtained from satellite images and related reflection in the red region (maximum absorption near chlorophyll $\alpha$ ) and the near-infrared (NIR) through the following expression: NDVI = (NIRRED) / (NIR + RED) in the satellite image. This index represents the difference in absorption and reflection of the red wavelength, which is strongly absorbed by the vegetation and the wavelength of the near infrared, which is strongly reflected by green vegetation(16).

The basis of the relationship between NDVI and green biomass seem to be related to the amount of photosynthetically active radiation absorbed by the canopy(17). NDVI ranges from -1 to 1 ; large values of this index indicate that the surface of the earth is covered with dense, healthy vegetation, i.e. that is no stress, moisture deficits, pests or diseases, while negative values indicate the presence of clouds, snow, water or bare ground(18). NDVI images handled corresponds to the sum of images for ten days (decadal compounds). For this study the images of the season vegetative growth were used to obtain the values of this index(14).

\section{Runoff}

The method used was based on the determination of laminar flow(19). With the information of rainfall (PP in $\mathrm{mm}$ ) and surface runoff expressed as runoff depth, the runoff coefficient (CE) and the threshold for initiating rain runoff $\left(\mathrm{P}_{0}\right)$, according to the parameter of the linear model runoff as proposed by Blackburn et al(20): 
activa absorbida por el dosel(17). El intervalo de valores del NDVI va de -1 a 1 ; valores grandes de este índice indican que la superficie de la tierra está cubierta con vegetación densa y saludable, es decir, que no presenta estrés por déficit de humedad, plagas o enfermedades, mientras que valores negativos indican la presencia de nubes, nieve, agua o suelo desnudo(18). Las imágenes de NDVI que se manejaron corresponde a la suma de imágenes durante diez días (compuestos decenales). Para este estudio se utilizaron las imágenes de la temporada de crecimiento vegetativo para obtener los valores de este índice(14).

\section{Escurrimiento}

El método usado fue el de la determinación de la lámina escurrida(19). Con la información de la precipitación pluvial (PP en $\mathrm{mm}$ ) y el escurrimiento superficial expresado como lámina escurrida, se estimó el coeficiente de escurrimiento (CE) y la lluvia umbral para iniciar el escurrimiento $\left(\mathrm{P}_{0}\right)$, de acuerdo con el parámetro del modelo lineal de escorrentía propuesto por Blackburn et al(20):

Lesc $=\mathrm{CE}\left(\mathrm{PP}-\mathrm{P}_{0}\right)$

Donde $\mathrm{L}_{\mathrm{esc}}=$ lámina de escurrimiento medida $(\mathrm{mm}) ; \mathrm{CE}=$ coeficiente de escurrimiento (adimensional); $\mathrm{PP}=$ precipitación $(\mathrm{mm}) ; \mathrm{P}_{0}=$ precipitación necesaria para iniciar el escurrimiento $(\mathrm{mm})$.

El coeficiente de escurrimiento se estimó a partir de la lámina escurrida en varios lotes experimentales, que son sitios de $3 \times 22 \mathrm{~m}$ (66 $\mathrm{m}^{2}$ ) diseñados para colectar el agua de Iluvia escurrida, ubicados en sitios contrastantes del estado de Zacatecas, que son los municipios de Tabasco y Pánuco. Para generar los valores del CE y $P_{0}$, se utilizaron los datos colectados en dichos lotes, los cuales se derivaron de mediciones de escurrimiento in situ durante varios ciclos de 1986 al 2004(21). Con la información obtenida, se hizo un análisis de regresión lineal, utilizando el paquete de computo SAS(11). Con el modelo se generó un
Lesc $=\mathrm{CE}\left(\mathrm{PP}-\mathrm{P}_{0}\right)$

Where $L_{\text {esc }}=$ depth runoff measurement $(\mathrm{mm})$; $\mathrm{CE}=$ runoff coefficient (dimensionless); $\mathrm{PP}=$ precipitation $(\mathrm{mm}) ; \mathrm{P}_{0}=$ rainfall necessary to initiate runoff $(\mathrm{mm})$.

The runoff coefficient was estimated from the runoff depth in several experimental plots, which

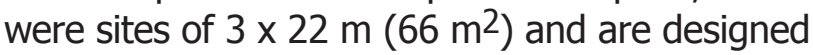
to collect rainwater from runoff. This was done from contrasting sites located in the State of Zacatecas, which are the municipalities of Tabasco and Panuco. To generate the values of the $C E$ and $P_{0}$, data collected in these lots were used, which were derived from in situ measurements of runoff over several cycles from 1986 to 2004(21). With the information obtained, linear regression analysis was carried out using the SAS computing package(11). With the model, a map was generated showing the runoff for the medium-sized open pastures in Zacatecas.

\section{Water erosion potential}

The universal soil loss equation (USLE)(23) was used to estimate levels of water erosion in Zacatecas(22), which considers the following factors:

$\mathrm{E}=\mathrm{RKLSCP}$

Where $\mathrm{E}$ is the erosion ( $\mathrm{t} / \mathrm{ha} /$ year); $\mathrm{R}$ is the factor of rainfall erosivity (MJ-mm/ha-h); $\mathrm{K}$ is the soil erodibility factor (t-ha-h / MJ-mm-ha); $L$ is the length factor of the slope (dimensionless); $S$ is the degree angle factor of the slope (dimensionless); $\mathrm{C}$ is the cropping management factor (dimensionless) and $P$ is the factor of practical mechanical control of erosion (dimensionless).

A map of potential erosion can detect the sites most vulnerable to erosion and is easy to build, as it eliminates the need to know the current crops status, native vegetation or the mechanical practices carried out to the soil. This means that vegetation components (C) and practical mechanical factor $(P)$ are not included in the 
mapa que muestra el escurrimiento para el pastizal mediano abierto de Zacatecas.

\section{Erosión hídrica potencial}

Para estimar los niveles de erosión hídrica en Zacatecas(22) se utilizó la ecuación universal de pérdida de suelo (USLE)(23), la cual considera los siguientes factores:

$\mathrm{E}=\mathrm{RKLSCP}$

En donde $E$ es la erosión (t/ha/año), $R$ es el factor de erosividad de la lluvia (MJ-mm/ha-h), $\mathrm{K}$ es el factor de erodabilidad del suelo (t-hah/MJ-mm-ha), L es el factor de longitud de la pendiente (adimensional), $\mathrm{S}$ es el factor de grado de la pendiente (adimensional), $C$ es el factor de la vegetación (adimensional) y $\mathrm{P}$ es el factor de práctica mecánica de control de la erosión (adimensional).

Un mapa de erosión potencial permite detectar los sitios de mayor vulnerabilidad a la erosión y es fácil de construir, ya que elimina la necesidad de conocer el estado actual de los cultivos, vegetación nativa y las prácticas mecánicas realizadas al suelo. Esto quiere decir que los componentes de vegetación (C) y el factor de práctica mecánica $(P)$ no se incluyen en la construcción de un mapa de erosión potencial, quedando la ecuación como sigue:

\section{$E=R K L S$}

El producto final es un mapa categorizado de valores de erosión hídrica que va desde 0 hasta valores mayores a $50 \mathrm{t} / \mathrm{ha}$. Aunque el mapa generado consiste de valores continuos, para facilitar su manejo y uso posterior, se decidió generar categorías predominantes, lo que simplifica la información, pero además crea una idea de áreas que tienen el mismo riesgo de ser afectadas por la erosión hídrica.

\section{Coincidencias entre mapas}

Para interpretar la coincidencia de los mapas analizados y los componentes principales convertidos a mapas, se comparó el componente construction of a map of potential erosion, the equation being as follows:

$E=R K L S$

The final product is a categorized map of water erosion values ranging from 0 to values greater than $50 \mathrm{t} / \mathrm{ha}$. Although the map generated consists of continuous values, to facilitate handling and later use, it was decided to generate predominant categories, which simplifies the information, but also creates an idea of areas that have the same risk of being affected by water erosion.

\section{Matches between maps}

To interpret the coincidence of the maps analyzed and the principal components converted to maps, the principal component 1 , which represented the grasslands health against a map of NDVI were compared. Also analyzed, were principal component 2 , which represented the surface runoff against another surface runoff and principal component 3 which estimated water erosion, against a map of potential water erosion. The goal was to set each map to the same number of classifications and values, so that matches exist between them. The numerical values were analyzed by chi-square test to assess differences. The geographic coincidences were compared using the IDRISI(13) program.

\section{RESULTS AND DISCUSSION}

In Figure 1 the spatial location of sampling in the field for assessing the current state of health in 34 grassland sites of Zacatecas is presented.

\section{Attributes of rangeland health}

According to the numerical values obtained with the use of the qualitative methodology for assessing rangeland health, the ecological attribute that is most noticeable is impaired biotic integrity (IB) as described by indicators 8 and 9 (surface resistance soil erosion and loss of land area) and 11 to 17 (soil compaction, 
principal uno, el cual representó la salud del pastizal contra un mapa de NDVI. EI componente principal dos, que representó el escurrimiento superficial, contra otro de escurrimiento superficial estimado y el componente principal tres, que representó la erosión hídrica, contra un mapa de erosión hídrica potencial. Se trató de ajustar cada mapa al mismo número de clases y valores, de manera que existieran coincidencias entre ellos. Los valores numéricos se analizaron mediante una prueba de Ji-cuadrada para valorar las diferencias. Las coincidencias geográficas se compararon mediante el programa IDRISI(13).

\section{RESULTADOS Y DISCUSIÓN}

En la Figura 1 se presenta la ubicación espacial de los muestreos en campo sobre la evaluación del estado actual de la salud en 34 sitios del pastizal de Zacatecas.

\section{Atributos de la salud del pastizal}

De acuerdo a los valores numéricos obtenidos con el uso de la metodología cualitativa para la evaluación de la salud del pastizal, el atributo ecológico que se aprecia más deteriorado es la integridad biótica (IB) descrita por los indicadores 8 y 9 (resistencia de la superficie del suelo a la erosión y pérdida de la superficie) y del 11 al 17 (compactación, grupos funcionales-estructurales, mortalidad de plantas, cantidad de matillo, producción anual, plantas invasoras y capacidad reproductiva de perennes) (Cuadro 1). Esto se corroboró por observación de campo, ya que en todos los predios se constata que los pastizales son sometidos al sobrepastoreo, el cual disminuye la cobertura vegetal y las plantas de mayor preferencia o palatabilidad por los diferentes tipos de ganado que pastorean libremente en cada sitio(24). Este atributo considera indicadores de suelo, pero se enfoca a los efectos de la disminución de diversidad, disminución de mantillo como fuente de materia orgánica, baja producción de materia seca, la presencia de plantas invasoras y la baja producción de perennes como pastizales, functional/structural groups, plant mortality, amount of mulch, annual production, invasive plants and reproductive capacity of perennials) (Table 1). This was corroborated through field observations, since all grasslands sites were subjected to overgrazing, which decreases the different types of vegetation cover and plants that are more preferred or palatable for cattle that graze freely in each site(24). This attribute considered indicators of soil, but focuses on the effects of declining diversity, such as less mulch which is a source of organic matter, low dry matter production, the presence of invasive plants and low production of perennial as pastures, caused mainly by excessive stocking rate, which causes a decrease in dry matter production, which is essential for the productive function of the rangeland.

The second most affected attribute was soil stability (SS) described by indicators 1 to 6 (small channels, patterns of runoff, stands and terracettes, bare soil, channels or waterways,

Figura 1. Distribución espacial de los sitios de muestreo en el estado de Zacatecas

Figure 1. Spatial distribution of sampling sites in the state of Zacatecas

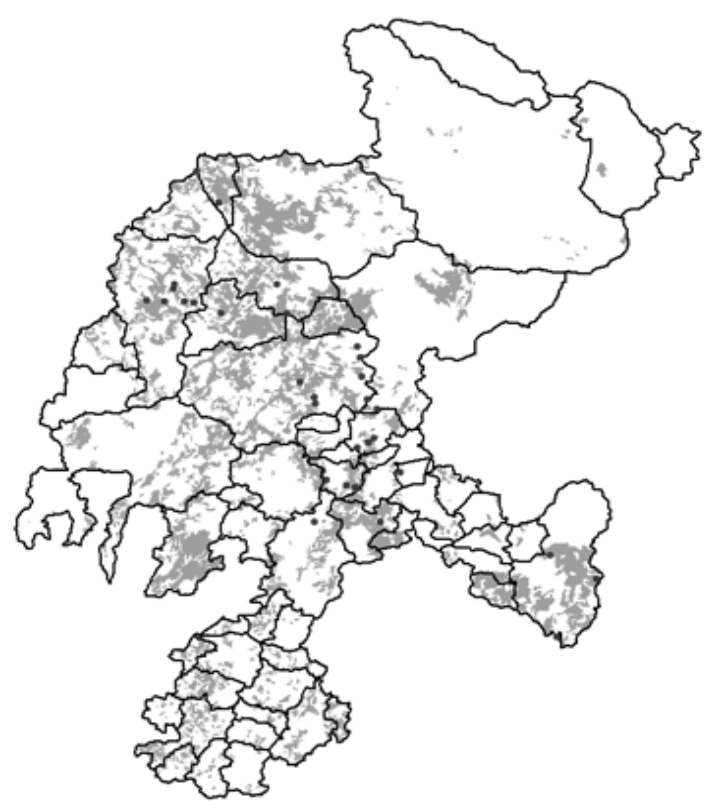


causado principalmente por una carga animal excesiva, y que repercute en la disminución de producción de materia seca, lo que es fundamental para la función productiva del pastizal.

El segundo atributo más afectado fue la estabilidad del suelo (ES) descrita por los indicadores 1 al 6 (canalillos, patrones de escurrimiento, pedestales y terracetas, suelo desnudo, canales y deposiciones de suelo) y 8 , 9, 11 (ya mencionados) (Cuadro 1). Todo este conjunto de indicadores conducen a mostrar dos efectos principales que afectan el suelo y que están íntimamente ligados, la pérdida de la capa superficial, la que al ser arrastrada, disminuye la infiltración y favorece el escurrimiento, provocando la inestabilidad del sistema suelo, lo cual fue corroborado al compararse con los sitios de referencia, de acuerdo a la metodología.

El tercer atributo y el que mostró menor afectación, es la funcionalidad hidrológica (FH) descrita por los indicadores 1 al 5, (ya mencionados) el 7 (movimiento de mantillo) y del 8 al 11 (ya mencionados) y 14 (cantidad de mantillo) (Cuadro 1). El menor efecto observado en la $\mathrm{FH}$, se explica por la reducida pendiente que presenta el pastizal mediano abierto, pero la preocupación mayor es la falta de cobertura vegetal que disminuye cada vez más, el arrastre de mantillo, ya que gran parte del agua de lluvia se escurre y no se infiltra y que conduce a una pérdida de fertilidad, lo que provoca daños en el pastizal, al alterar la composición de la comunidad vegetal (indicador 10, exclusivo de este atributo) y la capacidad de permitir la infiltración y favorecer el escurrimiento.

Estos resultados advierten que la disminución de la cobertura vegetal está afectando tanto la estabilidad del suelo como la funcionalidad hidrológica. El efecto del sobrepastoreo sobre la estabilidad del suelo y su impacto en la erosión hídrica ha sido documentado con anterioridad(25). Cualquier intervención tecnológica dirigida a reducir el impacto del wind erosion and deposited soil) and 8, 9, 11 (mentioned above) (Table 1). This set of leading indicators show two main effects affecting the ground/soil and are intimately connected, the loss of the surface layer, which after being pulled decreases and promotes the infiltration runoff, soil instability resulting system, which was confirmed when compared to reference sites, according to the methodology.

The third attribute showed less impairment, is the hydrologic function (HF) described by indicators 1 to 5, (already mentioned) 7 (movement of mulch) and 8 to 11 (mentioned above) and 14 (amount of mulch) (Table 1). The minor effect observed in HF is explained by the reduced slope of the rangelands. Nevertheless, the main concern is that the lack of vegetation cover decreases increasingly, thus reducing mulch due to erosion, since much of rainwater runoff does not infiltrate. This leads to a loss of fertility, causing damage to the pasture, altering the composition of the plant community (indicator 10, exclusive of this attribute) and the ability to allow infiltration and instead favors runoff.

These results warn that the decrease in vegetation cover is affecting both the stability of the soil and its hydrologic function. The effect of grazing on soil stability and its impact on water erosion has been documented previously(25). Any technological intervention aimed at reducing the impact of overgrazing, and the use of grazing systems, contribute to the reduction of the damage which is experiencing the pasture. In general, the overall result of the application of the methodology, according to the data collected from the 34 sites studied on a scale of 1 to 5 , is 3 , which places it at a medium health (average). This could be considered a limitation of the methodology of grassland health, since the diagnosis generates an average classification. It is unable to show the spatial variation. The spatial analysis, displays the health of grassland at a municipality level, as it will be presented. 
sobrepastoreo, como el uso de sistemas de pastoreo, contribuirá a la disminución del deterioro que actualmente sufre el pastizal. En general, el resultado global de la aplicación de la metodología, de acuerdo con los datos recabados de los 34 sitios estudiados, el promedio de valores obtenidos en una escala de uno a cinco, es de tres, lo que lo ubica en una salud media (promedio). Esta podría considerarse una limitante de la metodología de salud de pastizal, ya que el diagnostico se reduce a una categoría promedio, sin poder mostrar la variación espacial. El análisis espacial realizado, permite visualizar el estado de salud del pastizal a nivel de Municipio, como se presentará adelante.

\section{Comparación de métodos}

Para complementar la información observada por la metodología de Pellant et al(4) y facilitar el análisis de los 17 indicadores, se utilizó un análisis multivariado de componentes principales. Se decidió utilizar únicamente los

\section{Comparison of methods}

To complement the information observed by the methodology of Pellant et al(4) and facilitate the analysis of the 17 indicators, a multivariate principal component analysis was used. It was decided to use only the first three principal components (Table 2) since they provide the highest contribution, which better explains the variance. Coincidentally, in accordance with the magnitude and participation of each of the indicators, such components refer to the most important problems of pasture in Zacatecas, which are: rangeland health, runoff and water erosion.

The first three components provide $68 \%$ of the total variance, highlighted by the first, which provides $52 \%$. To interpret the meaning of each of the components characteristic values were assigned to each of the indicator vectors (Table 2 ).

Cuadro 2. Vectores característicos de los 17 componentes principales

Table 2. Characteristic vectors of the 17 principal components

\begin{tabular}{lccc}
\hline Health indicators of pasture & Health & Runoff & Water erosion \\
\hline Rills & 0.209400 & 0.371464 & -0.327846 \\
Water flow patterns & 0.259507 & 0.295391 & 0.132618 \\
Pedestals or terracettes & 0.187439 & 0.280939 & -0.072800 \\
Bare ground & 0.276962 & -0.006420 & 0.206804 \\
Gullies & 0.250695 & 0.389795 & -0.408056 \\
Wind-Scoured, blowout, or depositional areas & 0.162373 & 0.149985 & 0.196653 \\
Litter movement & 0.213522 & 0.199571 & 0.109461 \\
Soil surface resistance to erosion & 0.273290 & -0.022446 & 0.158760 \\
Soil surface loss or degradation & 0.266542 & -0.025000 & 0.215383 \\
Plant community composition and distribution relative to infiltration and runoff & 0.298764 & -0.057320 & 0.117744 \\
Compaction layer & 0.151808 & -0.023168 & 0.078493 \\
Functional/structural groups & 0.216313 & -0.079540 & -0.063480 \\
Plant mortality/decadence & 0.148821 & -0.009697 & 0.160112 \\
Litter amount & 0.311061 & -0.378644 & 0.331094 \\
Annual production & 0.250558 & 0.064121 & 0.042531 \\
Invasive plants & 0.268820 & -0.482841 & -0.520122 \\
Reproductive capacity of perennial plants & 0.288762 & -0.299227 & -0.326272 \\
\hline
\end{tabular}


primeros tres componentes principales (Cuadro 2) por ser los de mayor aportación y que mejor explican la varianza. Coincidentemente y de acuerdo con la magnitud y participación de cada uno de los indicadores, dichos componentes hacen referencia a los problemas más importantes del pastizal de Zacatecas, como son: la salud del pastizal el escurrimiento superficial y la erosión hídrica.

Los tres primeros componentes resumen el $68 \%$ de la varianza total, resaltando el primero con un $52 \%$. Para interpretar el significado de cada uno de los componentes se utilizaron los valores de los vectores característicos asignados a cada indicador (Cuadro 2).

Salud del pastizal (componente principal uno) El primer componente principal calculado incluyó variables de suelo, agua y vegetación, los cuales hacen referencia, de forma general, a la salud del pastizal. A partir de los valores estimados de cada vector característico asignado a cada uno de los 17 indicadores, los cuales variaron de 0.15 a 0.31 , que al ser valores muy semejantes, es una indicación de que todos están involucrados y representan la salud general del pastizal, por lo que se decidió considerar este componente de esta manera.

Una vez estimado el mapa a partir del primer componente principal, con el sustento de un semivariograma, se infiere que los municipios que cuentan con pequeñas áreas de muy buena salud del pastizal son Sombrerete y Pinos.

Los municipios que cuentan con áreas extensas en media y buena salud del pastizal son: Sombrerete, Sain Alto, Fresnillo, Calera, Zacatecas, Genaro Godina, Cuauhtémoc, Villa García, Pinos, Monte Escobedo, Atolinga, Tepechitlán, Téul de González Ortega, Villa Nueva y Chalchihuites.

Los municipios con áreas de salud pobre son: Francisco Murguía, Río Grande, Saín Alto, Fresnillo, Valparaíso, Jerez, Cañitas de Felipe Pescador, Villa de Cos y Monte Escobedo, Miguel

\section{Rangeland health (principal component 1)}

The first principal component calculated variables included soil, water and vegetation, which refer, in general, to rangeland health. From estimates of values of each characteristic vector assigned to each of the 17 indicators, which ranged from 0.15 to 0.31 , indicates they are similar and that all are involved in the overall health of grassland. Hence, it was decided to define this principal component as such.

Once the map was estimated from the first principal component, with the support of a semivariogram, it was possible to infer that the municipalities with small areas of very good rangeland health are Sombrerete and Pinos.

The municipalities with large areas of rangeland in medium and good health are: Sombrerete, Sain Alto, Fresnillo, Calera, Zacatecas, Genaro Godina, Cuauhtémoc, Villa García, Pinos, Monte Escobedo, Atolinga, Tepechitlán, Teúl de González Ortega, Villa Nueva and Chalchihuites.

Municipalities with areas of poor health are: Francisco Murguia, Rio Grande, Sain Alto, Fresnillo, Valparaiso, Jerez, Cañitas de Felipe Pescador, Villa de Cos and Monte Escobedo, Miguel Auza, Juan Aldama, Francisco Murguia, and small areas of Rio Grande, Panuco, Pánfilo Natera and Pinos.

The classification of surface area shows that most corresponds to the medium classification (Table 3), followed by the good, poor and very good, respectively. For the period in which the assessment (2007) was performed, values of poor category accounted for only $3.5 \%$ of the total. This should be considered in the context of time due to weather conditions vary over time even within each locality. The results indicate that the health status of rangeland, in general, is in a medium condition, soil component being the most affected by decreasing vegetation cover due to overgrazing, which has been evidenced in Zacatecas by excessive stocking rate used. Such overgrazing was estimated at $140 \%(1)$, with a mean 
Auza, Juan Aldama, Francisco Murguía, y pequeñas áreas de Río Grande, Pánuco, Pánfilo Natera y Pinos.

La superficie asignada a cada categoría muestra que la mayor superficie corresponde a la categoría media (Cuadro 3), seguida por la categoría buena, muy buena y pobre, respectivamente. Para el periodo en que se realizó la evaluación (2007), los valores de la categoría pobre representaban sólo $3.5 \%$ del total. Esto debe considerarse en el contexto temporal debido a que las condiciones de clima varían a través del tiempo aun dentro de cada localidad. Los resultados indican que el estado de salud del pastizal, en general, se encuentra en una condición media, siendo el componente suelo el más afectado por disminución de la cubierta vegetal debido al sobrepastoreo, el cual ha sido evidenciado en Zacatecas por la excesiva carga animal utilizada. Dicho sobrepastoreo se estimó en $140 \%(1)$, con valores de coeficiente de agostadero promedio para el pastizal mediano abierto de 12 ha/UA en 2007(24). Sin embargo, no se debe olvidar el efecto de la sequía que afecta comúnmente los pastizales de este Estado. En el año 2011, la Comisión Nacional del Agua reportó que el $40 \%$ del territorio nacional registró el peor año con sequía en los últimos setenta años(26) y cuyo inicio fue desde 2009 y se mantuvo hasta 2012. Este periodo de sequía afectó sensiblemente la disponibilidad de forraje y el inventario animal, por lo que no se debe descartar la participación del clima en la disminución de la cubierta vegetal. Dicha disminución incrementa el escurrimiento superficial $y$, por consiguiente, acelera la erosión hídrica. Esta tendencia se observa mayormente en las áreas de pastoreo comunal del Estado.

Escurrimiento superficial (componente principal dos)

El segundo componente hace referencia al escurrimiento superficial, porque contiene vectores característicos de valor alto, que representan características de drenaje superficial stocking rate for rangeland of $12 \mathrm{ha} / \mathrm{AU}$ in 2007(24). However, the effect of drought that commonly affects the rangelands of this State must be always taken into account. In 2011, the National Water Commission reported that $40 \%$ of the country recorded the worst year of drought in the last $70 \mathrm{yr}(26)$ that began in 2009 and remained until 2012. This period of drought affected significantly the availability of forage and animal inventory; hence it is not possible to rule out the involvement of climate when vegetation cover decreases. Such decrement increases amount of surface runoff and therefore accelerates water erosion. This trend is mostly seen in communal grazing areas of the State.

\section{Surface runoff (principal component 2)}

The second component refers to surface runoff, because it contains high-value vectors characteristic representing surface drainage features, such as the formation of small channels and gullies, which, showed positive numeric value and that indicates as an increment of runoff values. By contrast, the eigenvectors of less weight, which influenced the decrease in runoff, are those that show a presence of mulch or natural water retention, which acts as a barrier and slows runoff. Also, runoff was decreased by the presence of plants and shrubs, which also contributed residues on the soil

Cuadro 3. Superficies estimadas con determinación de estado de salud con NDVI y con estudio cualitativo de salud del pastizal para el estado de Zacatecas

Table 3. Estimated surfaces to determine health status with NDVI and qualitative study of rangeland health for surfaces of the State of Zacatecas

\begin{tabular}{ccccc}
\hline \multicolumn{2}{c}{ NDVI } & & \multicolumn{2}{c}{ Study of rangeland health } \\
\cline { 5 - 6 } Surface (ha) & Classification & & Surface (ha) & Classification \\
\hline 50,618 & POOR & & 49,317 & POOR \\
909,067 & MEDIUM & & 915,361 & MEDIUM \\
421,353 & GOOD & & 419,890 & GOOD \\
14,185 & VERY GOOD & & 10,656 & VERY GOOD \\
\hline
\end{tabular}


como son la formación de canalillos y cárcavas, los cuales, por su valor numérico positivo, contribuyeron a incrementar los valores de escurrimiento. Por el contrario los vectores característicos de menor ponderación, los cuales influyeron en la disminución del escurrimiento, son la presencia de mantillo o retención natural de agua, el cual actúa como barrera y frena el escurrimiento superficial; asimismo, el escurrimiento fue disminuido por la presencia de plantas como los arbustos, que también contribuyeron con residuos sobre la superficie del suelo, contribuyendo a la disminución del escurrimiento superficial.

La pérdida de suelo por escurrimientos superficiales depende tanto de la cantidad, como de la intensidad de la lluvia. Los municipios que presentan las áreas de bajo escurrimiento superficial son: Saín Alto, Fresnillo y Cañitas de Felipe Pescador y pequeñas áreas de Río Grande y Valparaíso.

Los municipios que muestran las áreas de alto escurrimiento superficial son: Juan Aldama, Francisco Murguía, Pánuco, Veta Grande y una extensa área de Río Grande y Pinos. El Cuadro 4 muestra las hectáreas y clases de escurrimiento superficial. Los valores más altos de superficie con escurrimiento es la clase de escurrimiento medio y bajo, los valores alto y muy alto presentan superficies de menor tamaño.

Erosión hídrica (componente principal tres)

El tercer componente se denominó erosión hídrica, debido a que los valores de los vectores característicos de mayor ponderación positiva, son el suelo desnudo, la pérdida de suelo y la presencia de mantillo; el primero es el indicador de máxima erosión potencial y se corrobora con la presencia del indicador de pérdida de suelo; por otro lado la presencia de mantillo, reduce el escurrimiento e incrementa la cobertura y disminuye la erosión. Por otro lado, los valores característicos negativos, que son la presencia de plantas invasoras, presencia de surface, contributing to the decrease in surface runoff.

Soil loss by surface runoff depends on both the amount and intensity of rainfall. The municipalities with areas of low runoff are: Sain Alto, Fresnillo and Cañitas de Felipe Pescador and small areas of Rio Grande and Valparaiso.

The municipalities that show areas of high surface runoff are: Juan Aldama, Francisco Murguia, Panuco, Veta Grande and a large area of Rio Grande and Pinos. Table 4 shows the hectares and classifications of surface runoff. Highest values of areas with runoff were found with those classified with medium and low runoff, the high and very high values showed smaller areas.

\section{Water erosion (principal component 3)}

The third component was named water erosion because the characteristic values that have more positive weight are the indicators of bare ground, litter amount and soil surface loss or degradation. The first is the indicator of high erosion potential and is corroborated by the presence of soil loss indicators; moreover the presence of mulch reduces runoff and increases coverage and reducing erosion. On the other hand, negative eigenvalues, which indicate the presence of invasive plants, the presence of

Cuadro 4. Superficies estimadas de estudio de escurrimiento superficial y con estudio cualitativo de salud del pastizal para el estado de Zacatecas

Table 4. Estimated areas of the study of surface runoff and qualitative study of rangeland health for the state of Zacatecas

\begin{tabular}{lcrcc}
\hline \multicolumn{2}{c}{ Surface runoff } & & \multicolumn{2}{c}{ Study of rangeland health } \\
\cline { 1 - 2 } \cline { 5 - 6 } Surface (ha) & Classification & & Surface (ha) & Classification \\
\hline 292,173 & POOR & & 291,603 & POOR \\
796,160 & MEDIUM & & 819,028 & MEDIUM \\
189,763 & HIGH & & 174,447 & HIGH \\
117,128 & VERY HIGH & & 110,145 & VERY HIGH \\
\hline
\end{tabular}


cárcavas, canales, canalillos, y la capacidad reproductiva (presencia de macollos y material presente con semilla); todo esto último muestra que la disminución de los mismos, contribuye a reducir los valores de erosión hídrica y, por el contrario, su presencia incrementa los valores. Sin embargo, nos indica que no son elementos que contribuyen directamente en el proceso erosivo, del pastizal de Zacatecas en particular, y que la erosión hídrica presente en el pastizal mediano abierto, es principalmente del tipo laminar, sin la influencia directa de canales o cárcavas, que son comunes cuando los niveles de erosión hídrica son más altos.

Los valores numéricos de erosión hídrica variaron poco entre las categorías. Sobresale la categoría baja, seguido de la clase alta (extremos), con valores numéricos intermedios no muy distantes entre sí (Cuadro 5). Esto es una indicación que el proceso erosivo, aunque constante, no genera grandes valores. Valores máximos medidos en áreas de pastizal mediano abierto de Zacatecas, son del orden de $7 \mathrm{t} / \mathrm{ha}(27)$, por lo que se presentan valores bajos constantes. Dado que la capa de suelo susceptible de ser afectada por la erosión es de tamaño reducido, los valores medidos de erosión son de baja magnitud, subestimando de esta manera, el nivel de degradación real que se presenta en la zona y debe tomarse en cuenta el nivel de degradación previo de los sitios observados.

\section{VALIDACIÓN DE METODOLOGÍA}

\section{Salud del pastizal}

Para validar los resultados de aplicación de la metodología de salud del pastizal y la distribución espacial generada a partir de los componentes principales, se comparó la Figura 2 (derecha), con la imagen izquierda, la cual representa la medición de la biomasa verde de la vegetación nativa evaluada mediante el NDVI. La coincidencia entre ambas imágenes representa un $59.2 \%$ del total (Figura 2, izquierda). El valor de coincidencia categórica no fue diferente entre mapas (Ji-cuadrada, $P>0.05$ ) (Cuadro 4). Esto nos indica una gullies, channels, rills, and reproductive capacity (bunch of tillers with seeds); the latter shows that lowering them, helps to reduce water erosion values and, conversely, their presence increases the values. However, this indicates that these are not elements that contribute directly to the erosion process of the grasslands of Zacatecas in particular, and that water erosion present in the rangeland, is mainly laminar, without the direct influence of channels or gullies which are common when levels of water erosion are higher.

The numerical values of water erosion varied little between the different classifications or categories. Low classification is the most abundant, followed by the high classification, followed by the moderate classification, which is no very distant in numerical values (Table 5). This is an indication that the erosion process, although constant, does not generate large values. Maximum values measured in areas of rangelands in Zacatecas are about 7 t/ha(27), thus low values are common. Given that the ground layer that is susceptible to erosion is small, the measured erosion values have low magnitude. This may be causing underestimating the actual level of degradation that occurs in the zone and thus, it must be taken into account the previous level of degradation at the observed sites.

Cuadro 5. Superficie estimada de erosión hídrica potencial y coincidencia con estudio cualitativo de salud del pastizal para el estado de Zacatecas

Table 5. Estimated water erosion potential matched with a qualitative study of rangeland health for the State of Zacatecas area

\begin{tabular}{lcccc}
\hline \multicolumn{2}{c}{ Surface runoff } & & \multicolumn{2}{c}{ Study of rangeland health } \\
\cline { 5 - 6 } \cline { 5 - 5 } Surface (ha) & Classification & & Surface (ha) & Classification \\
\hline 221,945 & VERY LOW & & 230,703 & VERY LOW \\
432,448 & LOW & & 445,921 & LOW \\
268,500 & MODERATE & & 256,797 & MODERATE \\
315,997 & HIGH & & 305,738 & HIGH \\
156,334 & SEVERE & & 156,058 & SEVERE \\
\hline
\end{tabular}


distribución semejante de valores entre un mismo número de categorías. Sin embargo, para fines de validación de la metodología, el valor más importante es el de la coincidencia numérica por ubicación geográfica. El valor obtenido resultó semejante al estimado de varianza que representa el primer componente principal, el cual fue de $52.5 \%$. Esto solo se menciona como una relación del alcance explicativo del primer componente, y no corresponde en ningún modo a una relación numérica esperada. Sin embargo, sí ayuda a comprender que un valor explicativo mayor del primer componente ayudaría a que la coincidencia hubiera sido mayor. Esto implica también la importancia de un mayor número de sitios de muestreo, lo que mejora la evaluación y contribuye a generar componentes principales que representen mayor porcentaje de varianza. Por otro lado, cabe mencionar que la salud hace referencia al conjunto suelo, agua y vegetación, y que al no contar con un mapa especifico que presente la condición temporal del pastizal, se utilizó el mapa de NDVI, el cual estima una disminución o incremento del verdor de las plantas del pastizal, y aunque representa la suma de tres

\section{VALIDATION OF METHODOLOGY}

Rangeland health

To validate the results of application of the methodology of rangelands health and spatial distribution generated from the principal components, Figure 2 (right) was compared with the left image, which represents the measurement of green biomass assessed of the native vegetation by NDVI. The coincidence between both images represents a $59.2 \%$ of total (Figure 2, left). The classification values coincidence did not differ between maps (Chisquare, $P>0.05$ ) (Table 4). This indicates a similar distribution of values among the same number of categories. However, for purposes of validation of the methodology, the most important value is the numerical coincidence by geographic location. The value obtained was similar to the estimated variance; it represents the first principal component, which was $52.5 \%$. This result is only mentioned in an explanatory scope of the first component, and does not correspond in any way to a numerical value expected. However, it helps to understand that a greater explanatory value of the first component would have helped increase the

Figura 2. Distribución espacial de superficie con el estado de salud del pastizal

Figure 2. Spatial distribution of surface with the health of grassland

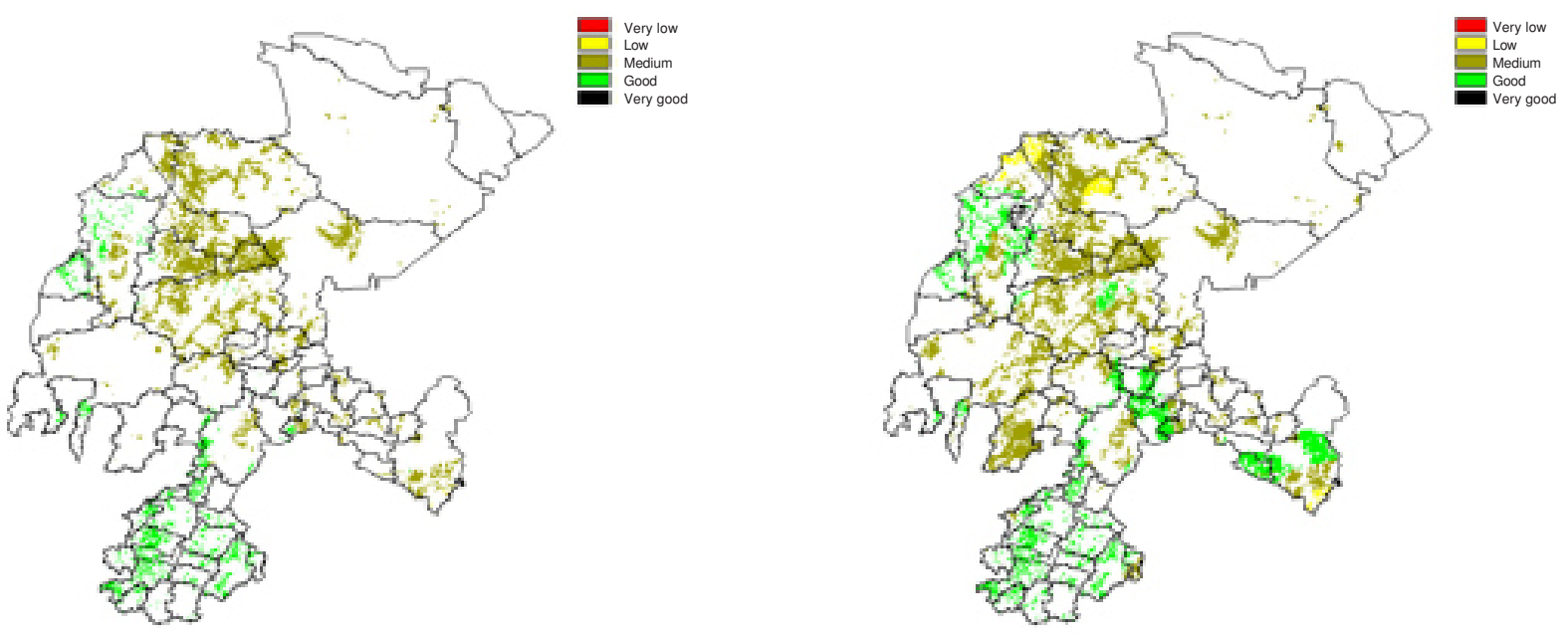

Right= generated from the principal components for the State of Zacatecas; Left= spatial coincidence when compared to the estimate generated from the use of NDVI. 
años, y resume en ellas el final del año (primera decena de octubre), el mapa representa sólo un acercamiento al complejo denominado salud general del pastizal. Las coincidencias se presentaron en los sitios más estables, en términos de productividad, y con esto se corrobora que ambos métodos expresan una misma condición del pastizal. Por lo anterior, se considera que al margen del mapa de referencia que se haya utilizado, la conversión a mapas por la vía del análisis de componentes principales, puede ayudar a precisar los resultados generados por la metodología utilizada, y puede colaborar para expresar de manera espacial, la toma de decisiones, dirigida a un sitio especifico, para la gestión del pastizal.

La validación del siguiente mapa generado por el segundo componente principal, que representa el escurrimiento superficial del pastizal de Zacatecas, fue comparada con la Figura 3 (izquierda) calculada mediante el componente principal y la estimación de escurrimiento generada por balance hídrico (derecha). La coincidencia en los valores de superficie por categorías no presentó diferencias (Ji-cuadrada, $P>0.05$ ) (Cuadro 4); sin embargo, similitude. This also involves the importance of a greater number of sample sites, which improves the evaluation and principal components and contributes to representing the highest percentage of variance. Furthermore, it is important to take note that health refers to all soil, water and vegetation, and the map of NDVI, which estimates a decrease or increase of "greenness" and although represents the sum of three years, and summarizes the results at the end of the year (first ten days of October), the map represents only an approximation to complex denominated rangeland health.

Matches are presented in the most stable sites in terms of productivity, and this is confirmed by both methods since they express the same rangeland condition. Therefore, it is hoped that reference map that was used and the conversion to maps by means of principal component analysis can help for clarifying results when the methodology is used. Thus, aiding others to express spatial decision making, targeting a site specific, for grassland management.

The validation of the map generated by the second principal component, which represents

Figura 3. Distribución espacial de superficie con escurrimiento superficial

Figure 3. Spatial distribution of surface runoff
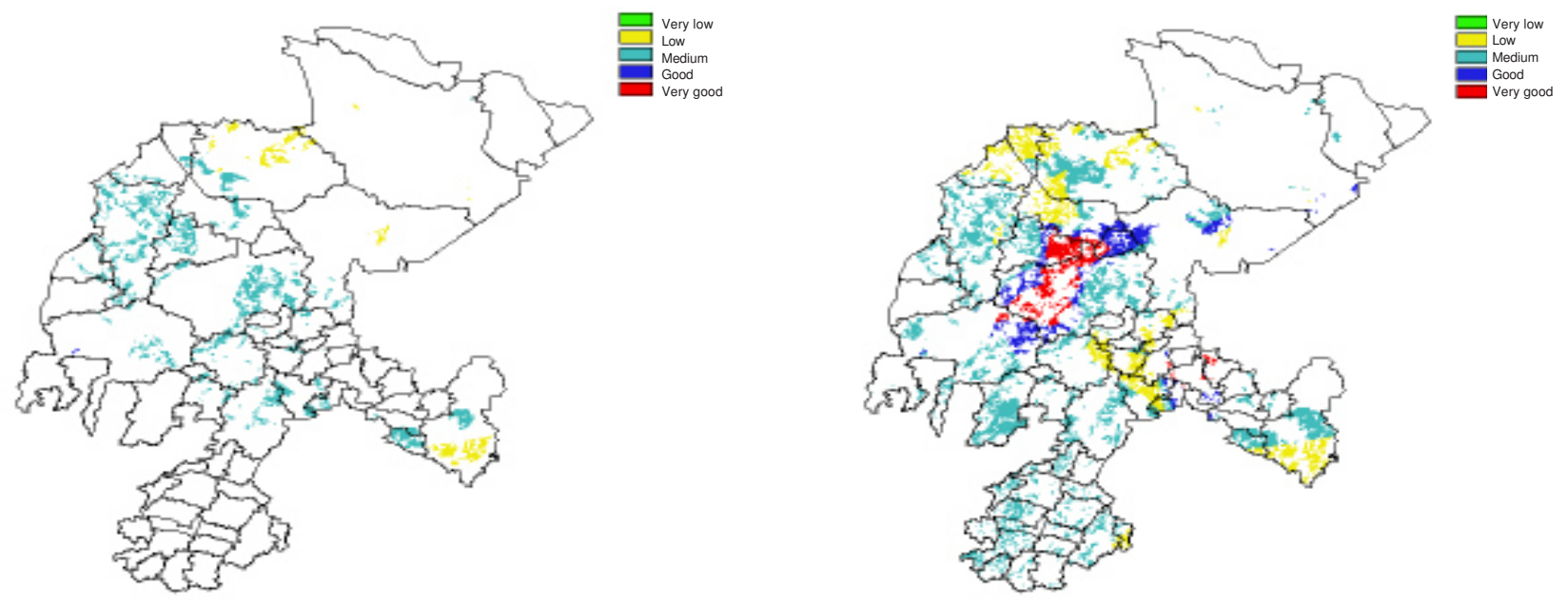

Right= estimated from the principal components; Left= spatial coincidence with a study of surface runoff in the State of Zacatecas. 
la coincidencia categórica y su localización geográfica, representó $31.2 \%$. Al igual que el anterior, el valor obtenido es mayor que la varianza representada por el segundo componente principal $(9.6 \%)$. Además, como en el componente principal anterior, la indicación de disminución de coincidencia espacial corresponde, exclusivamente, a una menor capacidad del segundo componente principal para explicar la varianza. La interpretación de los componentes principales y su ubicación geográfica ayudan a una mejor interpretación de los resultados de la metodología de salud del pastizal, y pueden ayudar a tomar decisiones de gestión como la rehabilitación del pastizal.

Para la validación de la erosión hídrica se comparó la Figura 4 (derecha) calculada mediante el uso de los componentes principales. Igual que en los casos anteriores, los valores categóricos no fueron diferentes $(P>0.05)$. La coincidencia categórica y su localización geográfica fue de $17.3 \%$. En este caso el valor está por encima del que representa el tercer componente principal (6\%). Al igual que los anteriores componentes, existe una relación entre las coincidencias con los mapas usados the runoff from rangelands of Zacatecas, was compared with Figure 3 (left) calculated using the principal components and the estimation of runoff generated by water balance (right). The coincidence in the values of categories of surfaces showed no differences (Chi-square, $P>0.05$ ) (Table 4). However, categorical matching and geographic location represented $31.2 \%$. Like the previous one, the retrieved value is greater than the variance represented by the second principal component $(9.6 \%)$. Moreover, as in the previous principal component, indication of decrease of spatial coincidence corresponds exclusively to a lower capacity of the second principal component to explain the variance. The interpretation of the principal components and their geographical location help a better interpretation of the results of the methodology of rangeland health, and can help make decisions of management such as the rehabilitation of the rangeland.

For validation of water erosion in the rangelands of Zacatecas, Figure 4 (right) was compared with that calculated by the use of the principal components. As in the previous cases, the classification values were not different $(P>0.05)$.

Figura 4. Distribución espacial de superficie con diferentes grados de erosión hídrica potencial

Figure 4. Spatial distribution of surface with different degrees of potential water erosion
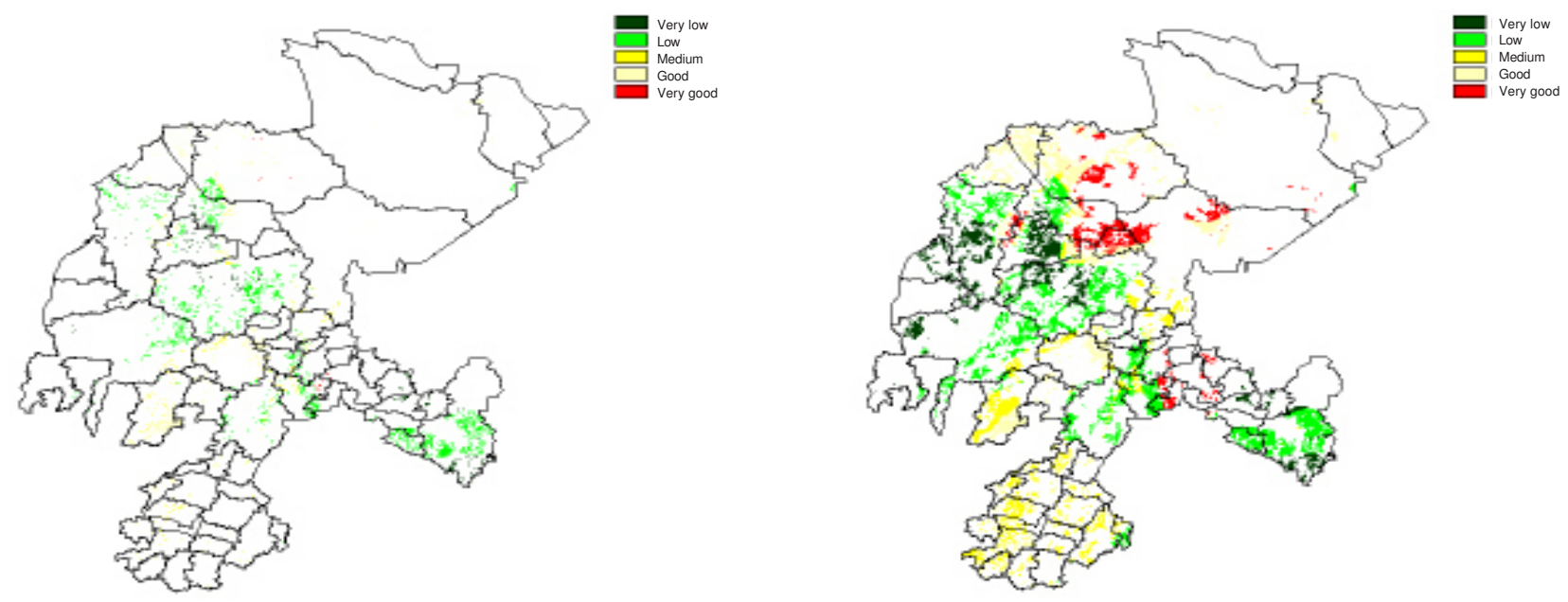

Right= estimated from the use of principal components; Left= matched to an estimate of estimated potential erosion from the use of Universal equation of soil loss. 
como referencia; en este caso de la erosión hídrica potencial y el generado por el tercer componente principal y el porcentaje de varianza explicado por el mismo. A medida que disminuyó la capacidad explicativa del mismo, disminuyeron las coincidencias. A medida que los componentes engloben una mayor cantidad de la varianza de los datos, ayudarán a explicar mejor los resultados y contribuirá a ubicar sitios no incluidos en el estudio. Esto último, en referencia a la posibilidad de representar geográficamente el estado de salud, representa una ventaja que puede complementar los estudios de monitoreo del pastizal. Esto significa una ampliación de los alcances de una metodología puntual y permite el uso de información adicional de estudios previos, ya sea de índole espacial o general. Esto hará posible además, utilizar herramientas como los sistemas de información geográfica, imágenes de satélite, etc., lo que mejorará el entendimiento de la condición temporal del pastizal, la gestión de la intervención tecnológica dirigida a sitios específicos de interés, de mejor capacidad de respuesta o productividad y una mayor eficiencia en el uso de recursos escasos.

\section{CONCLUSIONES E IMPLICACIONES}

De acuerdo con la metodología para determinar la salud actual del pastizal mediano abierto en el estado de Zacatecas, se ubica en el valor de tres, en la escala de uno a cinco, lo que representa una condición de salud media, en el año en que se realizó el estudio. La coincidencia entre mapas generados por componentes principales y mapas de referencia fue de 59.2, 31.2 y $17.2 \%$, lo que equivale a la varianza estimada por los componentes principales y permitió validar la correspondencia entre ambos. La semejanza de valores da confianza sobre el uso de una metodología cualitativa de aplicación rápida, confiable y económica. Una implicación del estudio realizado es la posibilidad de ampliar los resultados hacia sitios ecológicos similares no muestreados, y facilitar la incorporación de los resultados a análisis de tipo espacial, que permitan dirigir la intervención tecnológica hacia
The categorical matching and geographic location was $17.3 \%$. In this case, the value is higher than the third principal component (6\%). Like the above components, there is a relationship between matches with maps used as a reference; in this case the water potential erosion and that generated by the third principal component can be explained by the percentage of variance. However, as the explanatory power declined thereof matches decreased. As components encompass a greater amount of variance of the data, they will help to better explain the results and help locate sites not included in the study. The latter, referring to the possibility of representing geographically health status, represents an advantage that can complement rangeland monitoring studies. This means an extension of the scope of the methodology and allows the use of additional information from previous studies, either spatial or general nature. This will also enable to further use tools such as geographic information systems, satellite images, etc., which will improve the understanding of the temporal rangeland condition. Thus allowing for management of specific sites in terms of technological intervention, better response capacity or productivity and greater efficiency in the use of scarce resources.

\section{CONCLUSIONS AND IMPLICATIONS}

According to the methodology to determine the current health of the rangelands in the State of Zacatecas, it has a value of three, on the scale of one to five, representing a condition of medium health, in the year the study was conducted. The overlap between maps generated by principal components and reference maps were 59.2, 31.2 and $17.2 \%$, equivalent to that variance estimated by the principal components and allowed to validate the relationship between the two. The similarity of values gives confidence about using a qualitative methodology for a fast, reliable and economical application. One implication of the study is the possibility to extend the results to similar ecological sites not sampled, and facilitate 
sitios específicos de interés, con lo que se puede mejorar la eficiencia del uso de recursos escasos.

\section{LITERATURA CITADA}

1. Echavarría CFG, Medina GG, Rumayor RAF, Serna PA, Salinas GH, Bustamante WJG. Diagnóstico de los recursos naturales para la planeación de la intervención tecnológica y e ordenamiento ecológico. INIFAP. CIRNOC. Libro Técnico No 10. 2009.

2. Serna PA, Echavarría CFG. Niveles de degradación del suelo de un pastizal semiarido: II Diferencias en productividad. IV Simposio internacional de pastizales. San Luís Potosí, S.L.P. 2007:163-171.

3. Echavarria CFG. Recurso suelo, clasificación, uso, degradación y disponibilidad. En: Mojarro DF, et al editores. Agua subterránea en Zacatecas. Universidad Autónoma de Zacatecas. México, DF. 2013:97-133.

4. Pellant $M$, Shaver $P$, Pyke DA, Herrick JE. Interpreting indicators of rangeland health, version 4 . Technical Reference 1734-6. U.S. Department of the Interior, Bureau of Land Management, National Science and Technology Center, Denver, CO. BLM/WO/ST-00/001+1734/REV05. 2005.

5. Pyke DA, Herrick JE, Shaver P, Pellant M. Rangeland health attributes and indicators for qualitative assessment. J Range Manage 2002;55:584-597.

6. INEGI. Anuario Estadístico de Zacatecas. Instituto Nacional de Estadística y Geografía, Gobierno del Estado de Zacatecas. 2011.

7. García E. Modificaciones al sistema de clasificación climática de Köppen. 2a ed. México: Instituto de Geografía, UNAM; 1973.

8. Palacio-Prieto JL, Bocco G, Velazquez A, Mas J, TakakiTakaki F, Victoria A, et al. La condición actual de los recursos forestales en México; Resultado del Inventario Forestal Nacional 2000. Investigaciones Geográficas, Boletín del Instituto de Geografía. 2000;(43):183-202.

9. COTECOCA. Comisión Técnico Consultiva para la Determinación Regional de los Coeficientes de Agostadero. Memoria para el estado de Zacatecas y Aguascalientes. SARH- Subsecretaria de Ganadería. México. 1980.

10. Universidad Nacional Autónoma de México (UNAM). Cartas del inventario forestal, escala 1:250,000. 1993.

11. SAS Institute Inc. SAS technical report $p, S A S / S t a t$ software: Principal Components Analyses, Release 8.2, SAS Inc. Cary, NC. 2001.

12. Robertson GP. GS Geostatistics for the environmental sciences. Plainwell, Michigan USA: Gamma Design Software; 1995.

13. Eastman JR. IDRISI Selva. Worcester, MA: Clark University; 2012.

14. Medina GG, Gutiérrez LR, Echavarría CFG, Amador RMA, Ruiz CJA. Estimación de la producción de forraje con imágenes de satélite en los pastizales de Zacatecas. Tec Pecu Mex 2009;47(2):135-144.

15. Tucker $\mathrm{CJ}$. Red and photographic infrared linear combinations for monitoring vegetation. Remote Sens Environ 1979;8:127150. the incorporation of the results to analysis of spatial type. Thus, allowing for direct technological intervention to specific sites of interest, which can be used to improve the efficient use of scarce resources.

End of english version

16. Hill MJ, Vickery $\mathrm{PJ}$, Furnival EP, Donald GE. Pasture land cover in eastern Australia from NOAA-AVHRR NDVI and classified Landsat TM. Remote Sens Environ 1999;67:3250.

17. Sellers PJ. Canopy reflectance photosynthesis, and transpiration. Int J Remote Sens 1985;6:1335-1372.

18. Yin Z, Williams THL. Obtaining spatial and temporal vegetation data from Landsat MSS and AVHRR/NOAA satellite images for a hydrologic model. Eng Remote Sens 1997;63:69-77.

19. Bustamante, WJG, Echavarría CFG, Cabral AFJ, Serna PA, Mojarro DF, Bañuelos VR. Comparación de métodos de estimación de evapotranspiración en la evaluación de la recarga de los acuíferos del estado de Zacatecas. XII Semana Internacional de Agronomía. UJED-FAZ. Gómez Palacio Dgo. 2006.

20. Blackburn WH. Impacts of grazing intensity and specialized grazing systems on watershed characteristics and responses. In: Developing strategies for rangeland management. Nat Res Counc. Nat Acad Sci. Boulder, Colorado and London, England: Westview Press; 1984:927-1000.

21. Echavarría CFG, Medina GG, Gutiérrez LR, Serna PA. Identificación de áreas susceptibles de reconversión de suelos agrícolas hacia agostadero y su conservación en el ejido Pánuco, Zacatecas. Tec Pecu Méx 2004;42(1):39-53.

22. Echavarría CFG, Medina GG, Bravo LA. Estimación de la erosión hídrica en nopal nativo y cultivado en el estado de Zacatecas. Congreso Internacional. Conocimiento y aprovechamiento del nopal. Zacatecas. México. 2003:327333.

23. Wischmeier $W H$, Smith DD. Predicting rainfall erosion losses. A guide to conservation planning. USDA, Agric Handbook 537, U.S. Government. Printing Office. Washington, DC. USA. 1978.

24. Gutiérrez LR, Medina GG, Amador RMD. Carga animal del pastizal mediano abierto en Zacatecas. Folleto informativo No 36. CIRNOC. INIFAP. 2007.

25. Echavarría CFG, Serna PA, Bañuelos VR. Influencia del sistema de pastoreo con pequeños rumiantes en un agostadero del semiárido Zacatecano: II Cambios en el suelo. Tec Pecu Mex 2007;45(2):177-194.

26. Velásquez VMA, De Avila AA, Gutiérrez LR, García EG. Prácticas de restauración de suelos para la conservación del agua. CIRNOC. INIFAP. Folleto Técnico N 46. 2012.

27. Serna PA, Echavarría CFG. Caracterización hidrológica de un pastizal comunal excluido al pastoreo en Zacatecas, México. I. Pérdidas de suelo. Téc Pecu Méx 2002;40(1):3753. 
